\title{
Work-Life Balance Practices on Employees Job Performance of Selected Banking Sector in Malaysia
}

Shahidah Bt Ahmad Suhaimi ${ }^{1}$, Kamilah Bt Seman ${ }^{2}$

${ }^{1,2}$ Universiti Tenaga Nasional, Malaysia

\begin{tabular}{|c|c|}
\hline ARTICLE INFO & \multirow{7}{*}{$\begin{array}{l}\text { The purpose of this study is to investigate the influence of work-life } \\
\text { balance practices (e.g., flexible working options, employee assistance } \\
\text { program, and leave programs) on employee's job performance in } \\
\text { banking sector. This research focusing on employees as respondents } \\
\text { from banking sector in Klang Valley, Malaysia. Data were collected } \\
\text { from } 100 \text { samples by which data were collected through online surveys } \\
\text { from selected banks in Klang Valley and were analyzed through } \\
\text { statistical software. The Pearson correlation analysis was conducted } \\
\text { between independent variables and dependent variable. The result } \\
\text { shows to accept the hypothesis that work-life balance practices have } \\
\text { positive relationship with employees' job performance in banking } \\
\text { sector. This finding could help and promote the management of } \\
\text { companies to practice and to provide the work-life balance policies for } \\
\text { employees in banking sector.) }\end{array}$} \\
\hline Article history: & \\
\hline Received: January 2, 2019 & \\
\hline Revised: February 27, 2019 & \\
\hline Accepted: March 20, 2019 & \\
\hline Keywords: & \\
\hline $\begin{array}{l}\text { Work Life Balance, } \\
\text { Employee Performance, } \\
\text { Flexible Hours, } \\
\text { Banking Sector, } \\
\text { Work Life Balance Practice }\end{array}$ & \\
\hline
\end{tabular}

\section{Clonflict of Interest:}

None

\section{Funding:}

None

Corresponding Author: Shahidah Bt Ahmad Suhaimi, ${ }^{2}$ Department of Human Resource Management, Universiti Tenaga Nasional, Malaysia

(C) ( ( ) $\begin{aligned} & \text { C Shahidah Bt Ahmad Suhaimi, Kamilah Bt Seman } \\ & \text { This is an open access article under the CC BY-SA 4.0 international license. }\end{aligned}$

\section{Introduction}

In recent years, most employees are aware of the necessity to have a balance between work and life (Omar et al., 2015). The trends in the work environment, challenges of globalization, the demand of work, the working hours and technology complexity contributes to the challenges facing by employers to practice work-life balance in the organization towards their employees (Darcy et al., 2010). According to Obiageli et al., (2015), to remain the productivity level of employees, the work-life balance incentives should be continuously offered. He also mentioned that most of the Nigerian bank employees faced work-life balance issues because of long working hours and overload tasks. In 2013, the turnover rates of Malaysia financial services industry was increased to 13.3\% (Tan and Wong, 2015). The changes in the nature of work for bank employees have impacted by the working schedules which diminish employee's quality of life (Philipp et al., 2015).

Based on Aslam (2015) study, it shows that major changes in an employee performance are due to work-life balance. Stress, burnout and depression are part of health problems which indicates of an overworked worker (Omar et al., 2015) that gives significant impact on employee job performance (Bashir and Ramay, 2010). Ashfaq et al., (2013) also argued that imbalances between work and life are likely impacted employee performance (Dissanayaka and Ali, 2011). Work-life balance not only contributes to personal benefits, but also business benefits that result in productivity and performance. 


\subsection{Work-Life Balance}

An affirmative interaction between family and work life balance may improve employee's quality of life (Philipp et al., 2015). According to Gulbahar et al., (2014), work life balance is an equal arrangement between work and life. It is a long term process for large organization to support work life balance. This study found that there is a significant relationship between work life balance and organizational commitment. In addition, Khatri and Behl (2013) stated that the concept of work-life balance is based on the notion that paid work and personal life should be seen less as competing priorities than as complementary elements of a full life.

Furthermore, Moore (2007) cited in (Noor, 2011) mentioned that most of the current studies on work-life balance were investigating the effects of work-life balance not only towards organization but also to improve the productivity level of employees. Moreover, equal between work and life also will reduce the intention to leave the organization (Pradana and Salehudin, 2015). Moreover, it can alleviate job stress (Chiang, Birtch, and Kwan, 2010).

Darcy et al., (2012) argued that the results of work-life benefits are impacted based on the demographic profiles and populations of employees. Western organization, the employers tended to have limited policies on work-life balance such providing child-care, elder care, gymnasium and quarters for employees and family (Gachunga and Muchiti, 2015; Tavassoli and Sune, 2015).

Kamau et al., (2013) studied on how flexible working hours, leave policies and employee assistance programs affect employee's job performance. Based on their study, authors revealed that majority of the employees agree that flexible working hours have allowed them to balance their work and life commitments. Employees Assistance Programmes (EAP) would also help them to handle their personal commitment without affecting their performance (Chiang et al., 2010). Besides that, leave programs also has strong significant correlation with employees performance.

\subsection{Flexible Working Hours}

Gachunga and Muchiti (2015) stressed the flexible working hours as the working time or schedules that allows employees to choose their start and finish hour with the condition a certain number of hours are completed. Moreover, most of this policies promotes the employees to work for part time, telecommuting (working from home), job-sharing, days off and many other options (Florida, 2015; Noor, 2011). In addition, maternity and paternity leaves also part of work-life balance policies (Shagvaliyeva and Yazdanifard, 2014).

However, work-life balance might be not practiced when the employees are expected to work more than normal hours at their workplace which shortens the time for activities with family and other personal commitments (Chiang et al., 2010; O'Brien and Hayden, 2016). The trends of women working nowadays has makes them neglects their obligations as a wife and a mother and such policy will motivates the employees especially working women (Paul, Dutta, and Saha, 2015).

Shagvaliyeva and Yazdanifard (2014) stressed that the flexible working time not only beneficial for employees but also an exceptional step for employers to retain highly qualified people in the organization. Altindag and Siller (2014) supported that flexible working hours lead to job loyalty.

\subsection{Flexible Working Hours and Employee Performance}

Keino and Kithae (2016) revealed that work life balance factors such as long working hours, overtime, lack of vacation, neglect the family responsibilities and family work conflicts were negatively affects the employees performance. Meanwhile, Mungania (2016) proposed that managers should consider to give the flexibility to their employees to start and end their work as long as they meet their target. It is because based on the study; flexible work time will influence organizational performance.

Furthermore, the flexible hours gives the control for employees to coordinate their work and life duties. (Shagvaliyeva \& Yazdanifard, 2014) They added that with the flexibility, it contributes to overall employees' job satisfaction which resulted in a better performance. While, Altindag \& Siller (2014) found out flexible working hours as one of the factors has contributed to job loyalty and high employees' performance. Besides that, Altindag and Siller (2014) found that flexible working methods are very important practices to sustain employee performance. Gachunga and Muchiti (2015) also found that flexible working schedule was the most significant factor and had a positive relationship with employee's productivity.

\subsection{Employee Assistance Programme}

Employees Assistance Programme (EAP) is a programme which will help employer to identify problems that will affect their employee's well-being negatively and dealing with stressful situations. Initially, EAP began with occupational alcohol program and evolve to other health assessment programme in workplace (Waehrer et al., 2016). This EAP offers employees not only for job-related issues but also outside work-related such as counselling for depression and alcohol or drugs problems. 
In addition, organization also offers and advisory services such legal and financial services (Lekgothoana and Schultz, 2014). Based on Adigun and Bello (2014) the EAP was positively influence employee commitment in the manufacturing companies. Authors stated that organization should understand the needs of their employees in order to provide adequate working conditions.

\subsection{Employee Assistance Programme and Employee Performance}

EAP also was significantly affect employees' performance. In addition, Kipkemoi et. al (2016) found that EAP have a significant effect on employee's performance. Other research also found that the presence of employee assistance programme will gives positive employees' performance in banking sector (Kamau et al., 2013)

\subsection{Leave Policy Program}

Based on a study conducted in selected commercial banks in Lagos state, authors found that leave policy and service delivery have a significant positive relationship. It means that leave policy can motivate the employees to perform effectively and efficiently which will lead to the increasing in their performance. So, the researchers will suggest that managers should provide various work life balance incentives which will improves employees' performance (Obiageli et al., 2015). The researchers also defined the leave policy program as the number of days that employees allowed to be absent from their position in the organization without any significances.

According to Kamau et al., (2013), most of the employees will feel driven after taking leaves. In United States, there is a national policy on leave which employees are eligible to take paid leave such maternity or family leave which might reduce work-life conflicts (Allen et al., 2014).

\subsection{Leave Policy Program and Employee Performance}

In motivating employees to be more efficient and provide excellent service delivery, leave policy has played an important role to remain the productivity of employees. Hence, it could improve the work-life balance of employees and positively significant to employees' performance (Obiageli et al., 2015).

\subsection{Employee Performance}

The indicator on how well the employees performed in their job, it can be seen on their behaviour towards his/her job (Mwebi and Kadaga, 2015). However, they claimed there are many requirements need to determine on their work-related behaviour which might be different between one positions to another especially the work standards for each organization. Furthermore, Dissanayaka and Ali (2011) defined employee performance as the accomplishment of the task assigned completed within the time given. This show the goals of the organization are achieved.

High employees' performance enables organization to fully utilize the capability their talents. This resulted to motivated employees in contributing their energy and efforts which might give positive impacts to the organization (Obiageli et al., 2015). Though, Elnaga and Imran (2013) stressed that the employee performance should be constantly monitored in order to make corrective actions to any impractical standards.

A balance between work and personal well-being makes the employees focus on the outcomes which subsequently to well performed results. According to Bashir et al., (2013), employees' performance will be declined when they are disable to keep balance between their work and life. It is supported by Kim (2014), many studies have showed the positive relationship of work-life balance and employees' performance. Bashir et al., (2013) also added that most employees in banking sector experienced stress because imbalance between their family and working life which results in low job performance.

\section{Method}

This research was conducted through quantitative analysis. Quantitative analysis means that this study was conducted by distributing set of questionnaires to the respondents in order to get the empirical evidence. In this study, the questionnaire was measured by using 5 point Likert scale. Respondents were required to specify, (1) strongly disagree, (2) disagree, (3) neutral, (4) agree and (5) strongly agree.

Questionnaire was adopted from research by Kamau et al. (2013) with 26 items. The questionnaire consisted of close-ended items and divided into five parts: demographic profile, flexible working hours, role played by employee's assistance program, role played by leave policy and general employee's performance rating. Questionnaire was used because it provide a relatively cheap, quick and efficient way of obtaining large amount of information from a large sample of people. 


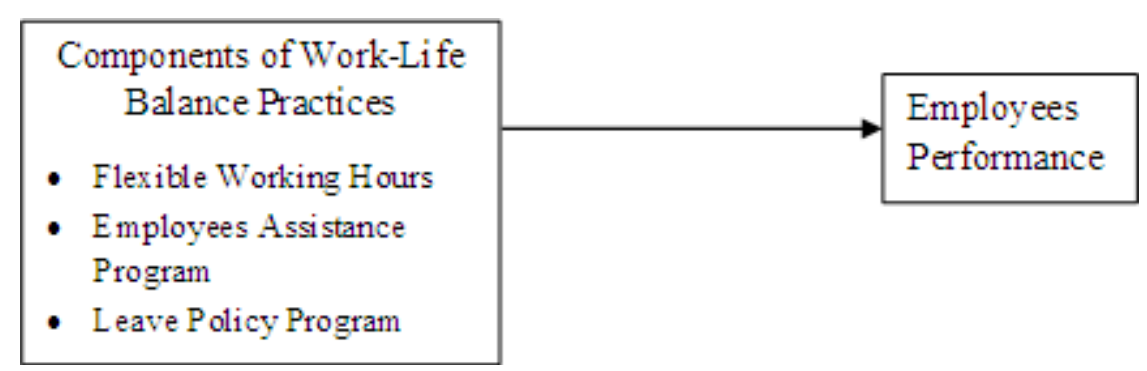

Figure 1. Research Framework

The independent variables were assessed by dividing into 3 components. First, flexible working hours were assessed by using 5 items. The second section, employees' assistance program was assessed by using 6 items. The last variable, leave policy program was assessed by using 5 items. Moreover, to measure the general employees' performance, it was rated based on 10 items. Based on the questionnaire, the respondents were asked from these items by five point-scale from strongly agree (5) to strongly disagree (1).

The data was collected from self-administered questionnaire through convenience sampling. Since the survey were distributed by online, this sampling method helps to yield sample that work in banks only which who are willing and readily available to take part. The sample size consists of 100 respondents. These respondents are chosen from total of three banks; Bank Islam Malaysia Berhad, Malayan Banking Berhad and CIMB Bank.

The duration of the data collection process took 2 months. However, due to time constraints, these questionnaires were distributed via online survey website; www.qualtrics.com since November 2016. Qualtrics is a simple to use web-based survey tool to conduct survey research. This tool was used because it easy to use and no software installation needed. Besides that, the process of this tool is simple and fast, and results are easy to access. The study was carried out by collecting data among bank employees that base in Klang Valley, Malaysia. The study was analyzed through descriptive statistics method and Pearson Correlation analysis. All data collected from the survey then are turned into meaningful information which was conducted through IBM SPSS version 24.0.

\section{Discussion and Recommendation}

\subsection{Gender}

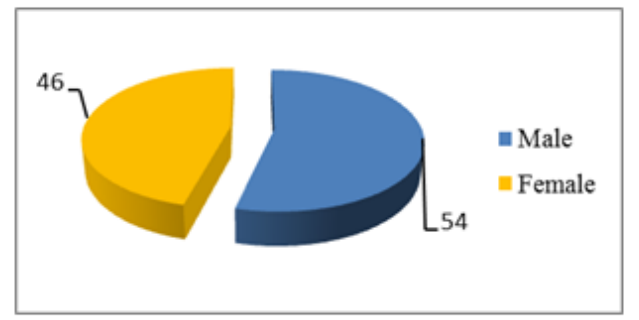

Figure 2. Gender

This study was conducted on 100 respondents from banking sector in Klang valley. Figure 2 shows that respondents consist of 54\% male and $46 \%$ female. It means that male respondents are more than female. 3.2 Age

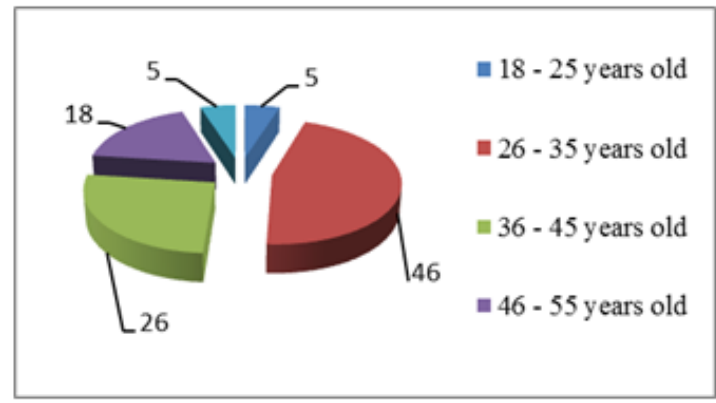

Figure 3. Age

Majority of the respondents are from 26 years old to 35 years old with $46 \%$. Then followed by the age of 36 years old to 45 years old (26\%), then 46 years old to 55 years old (18\%), lastly are the respondents between the age 18 years old to 25 years old and 56 years old and above $(5 \%)$. 


\subsection{Marital Status}

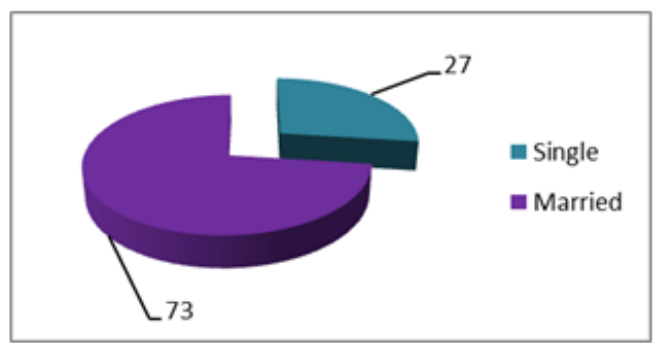

Figure 4. Marital Status

Based on Figure 4, most of respondents are married people with 73\%, while the single respondents represent $27 \%$ of the sample. Because of this situation, most of the respondents also have children which represent $64 \%$ of them.

\subsection{Education Level}

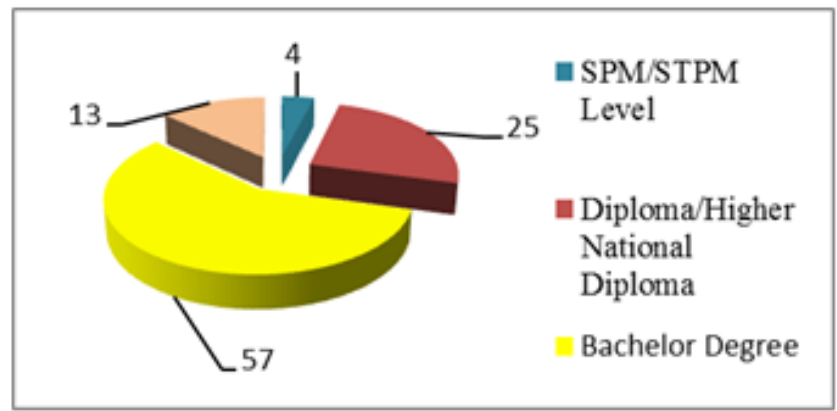

Figure 5. Educational Level

The above figure shows the education level of the respondents. Most of them are Bachelor Degree Holder which represent $57 \%$ of them, followed by Diploma or Higher National Diploma holder $(25 \%)$, then Master Degree holder (13\%), and finally followed by SPM or STPM holder which is only $4 \%$.

\subsection{Monthly Income}

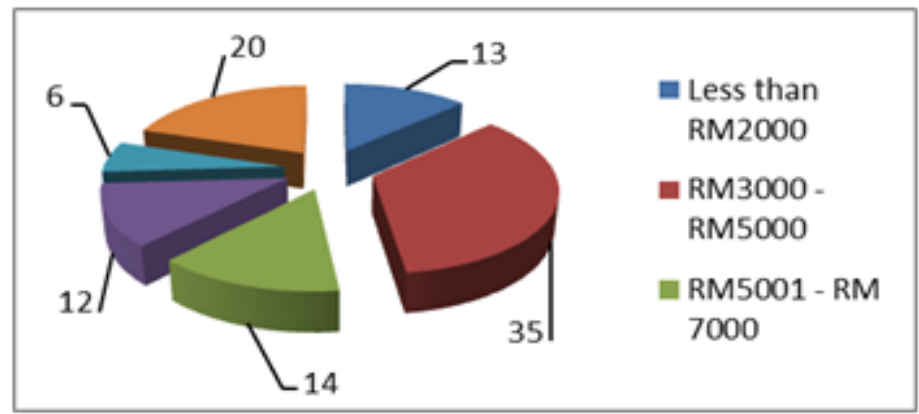

Figure 6. Monthly Income

Figure 6 shows the monthly income for the respondents. Majority of their income level are between RM3000 RM5000 with 35\%. Then followed by the income level more than RM1 1000 (20\%), between RM5001 - RM7000 is $14 \%$, less than RM2000 represent $13 \%$, between RM7001 - RM9000 represent $12 \%$, and lastly followed by the respondents who get RM9001 - RM11000 which is represent $6 \%$. 
3.6 Management Level

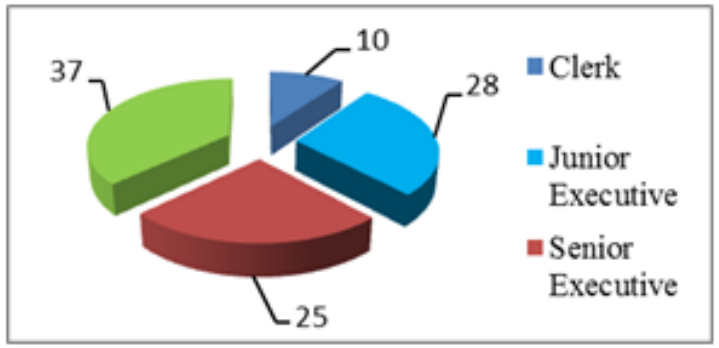

Figure 7. Management Level

Figure 7 shows that the majority of the respondents are Manager which represent 37\%, followed by Junior Executive which is $28 \%$, then Senior Executive (25\%) and lastly followed by clerk which is $10 \%$.

\subsection{Cronbach's Alpha Coefficient}

Table 1 shows the Cronbach's Alpha value is 0.920 , which is indicate that the items have relatively high internal consistency. The value of Cronbach's Alpha for flexible working hours is 0.905 (5 items), for Employee Assistance Program is 0.870 (6 items), and the value for leave policy program is 0.886 (5items).

Table 1. Cronbach's Alpha

\begin{tabular}{|lcc|}
\hline \multicolumn{1}{|c}{ Variable } & $\begin{array}{c}\text { Cronbach's } \\
\text { Alpha }(\boldsymbol{\alpha})\end{array}$ & $\begin{array}{c}\text { No of } \\
\text { Items }\end{array}$ \\
\hline Flexible Working Hours & 0.905 & 5 \\
Employee Assistance Program & 0.870 & 6 \\
\hline Leave Policy Program & 0.886 & 5 \\
Employee Performance & 0.932 & 10 \\
\hline $\begin{array}{l}\text { Independent and dependent } \\
\text { variables }\end{array}$ & 0.920 & 26 \\
\hline
\end{tabular}

\subsection{Pearson Correlation}

Table 2 shows the analysis of Pearson correlation in this study. Results indicate that there is a significant relationship between all work-life balance practices and employees' performance which is the significant value 95\% that P-value below 0.05. The flexible working hours, EAP, and leave policy positively correlate with employees' performance. Refer to the table above, flexible hours showed moderate positive significant relationship with $0.323^{* *}(\mathrm{p}<0.05)$. This result was supported by Kamau et al., (2013) which found that flexible working hours could influence the employees' performance.

Employee Assistance program (EAP) showed strong positive significant relationship with $0.578 * *(p<0.05)$. This result was supported by Kipkemoi et al. (2016) which revealed that EAP has a significant effect on employee performance. The study concludes that EAP needs to be scrutinized in the organization to ensure all the motivation practices are effective.

Leave policy showed moderate positive significant relationship with $0.397 * *(p<0.05)$. This result was supported by Obiageli et al. (2015) which stated that there is a significant positive relationship between leave policy and service delivery. The study revealed that leave policy motivate employee ability to deliver services efficiently and effectively.

The finding from the work revealed gender distribution of the respondents indicate that representing 54\% representing male and $46 \%$ female respectively, were involved in the study. This shows that both genders were affected by work life balance in the workplace. Every people need to prioritize their work role and personal commitment properly. This study also found that all the three components of work life balance were implemented in the banking sector but there is more room for improvement.

The finding from this study also revealed that there is a moderate positive relationship between flexible working hours and employee performance. It indicates the flexibility in working hours could influence how the employees perform their job. If employees obtained the flexible time, they can manage their work and life commitment (dual career perspective) accordingly. So, company should consider to apply the flexible working hours for their employees in order to improve their work performance. In line with Obiageli et al. (2015) high employee 
performance lead an organization to have greater opportunities for employees than those who have low performance. Because of that, it is important for the organization to identify the ways to improve their employee performance. Employees are happier when they are able to balance their work life demands.

Table 2. Pearson Correlation

\begin{tabular}{|c|c|c|c|c|c|}
\hline \multicolumn{6}{|c|}{ Correlations } \\
\hline & & $\begin{array}{l}\text { Flexible } \\
\text { Hours }\end{array}$ & EAP & $\begin{array}{l}\text { Leave } \\
\text { Policy }\end{array}$ & $\begin{array}{l}\text { Enployee } \\
\text { Performance }\end{array}$ \\
\hline \multirow{3}{*}{ Flexible Hours } & $\begin{array}{l}\text { Pearson } \\
\text { Correlation }\end{array}$ & 1 & $641^{* *}$ & $.524^{*}$ & $.323^{* *}$ \\
\hline & $\begin{array}{l}\text { Sig. (2- } \\
\text { tailed) }\end{array}$ & & 0 & 0 & 0.002 \\
\hline & $\mathrm{N}$ & 96 & 93 & 92 & 91 \\
\hline \multirow{3}{*}{ EAP } & $\begin{array}{l}\text { Pearson } \\
\text { Correlation }\end{array}$ & $641^{*}$ & 1 & $.679^{* *}$ & $.578^{* *}$ \\
\hline & $\begin{array}{l}\text { Sig. (2- } \\
\text { tailed) }\end{array}$ & 0 & & 0 & 0 \\
\hline & $\mathrm{N}$ & 93 & 97 & 94 & S3 \\
\hline \multirow{3}{*}{ Leave Policy } & $\begin{array}{l}\text { Pearson } \\
\text { Correlation }\end{array}$ & $.524^{-1}$ & $.679^{* *}$ & 1 & $.397^{\circ}$ \\
\hline & $\begin{array}{l}\text { Sig. (2- } \\
\text { tailed) }\end{array}$ & 0 & 0 & & 0 \\
\hline & $\mathrm{N}$ & 92 & 94 & 96 & S2 \\
\hline \multirow{3}{*}{$\begin{array}{l}\text { Employee } \\
\text { Performance }\end{array}$} & $\begin{array}{l}\text { Pearson } \\
\text { Correlation }\end{array}$ & $.323^{-1}$ & $.578^{* *}$ & $.397^{*}$ & 1 \\
\hline & $\begin{array}{l}\text { Sig. (2- } \\
\text { tailed) }\end{array}$ & 0.002 & 0 & 0 & \\
\hline & $\mathrm{N}$ & 91 & 93 & 92 & S5 \\
\hline
\end{tabular}

Management should support the employees by providing work-life balance incentives in order to foster a good relationship between the employees and the management team. This result was in line with the study conducted by (Altindag and Siller, 2014; Gachunga and Muchiti, 2015; Kamau et al., 2013)

Besides that, this study also revealed that Employees Assistance Program (EAP) had a significant positive correlation with employees' performance from banking sectors in Klang Valley. It shows that EAP at banking sectors in Klang Valley had its own influence on employees' performance. Based on this result, company should be considering to provide EAP to their employees. Company also understand and take into consideration the needs of their employees to provide an adequate working conditions for them. This result was supported with other researcher by (Adigun and Bello, 2014; Kamau et al., 2013; Kipkemoi et al., 2016).

In addition, this study also found that leave policy program had a significant positive correlation with the employee performance. Every employees are entitled to an annual leave within the calendar year. Based on this result, it can conclude that leave from work can change the working environment because employees can focus on their life commitment during that time. After they return back to their work, they felt motivated and can focus in doing 
their job and automatically will increase their performance. The result of this study was supported by (Kamau et al., 2013; Obiageli et al., 2015)

These three components can motivate employees to be more efficient in their work. If an organization want their employees remain productive and efficient, the organization must continue to improve on their work life balance incentives. Because of this situation, undeniably employees will perform better and will give their best services to the customers. This study also shows that work life balance is an important factor that lead to better employee performance.

There are several studies that supported the findings which show a positive relationship between flexible working hours and employee performance (Keino and Kithae, 2016), EAP with employee performance (Altindag and Siller, 2014) and leave policy program with employee performance (Obiageli et al., 2015).

This study gives the light to companies to provide policies align with the demand of family and personal life in any national labour market. The national policies especially on the leave policy should be announced to all companies in order to avoid unethical behaviour when it comes to employees' entitlement to take leave such maternity and sick leave.

Furthermore, superordinate has to ensure that employees understand the importance of flexible working hours for those who could not manage between work and life in normal working life. Likewise, the managers also need to provide training on how to have a work-life balance and living in healthy lifestyle which give the quality of life of employees.

\section{Conclusion}

This study concludes that the flexible working hours, EAP and leave policy program has a positive significant relationship with employee performance in banking sector in Klang Valley. Flexible working hours and leave policy program had a moderate positive relationship with employee performance while EAP had a moderate positive relationship with employee performance.

Since this study sought to establish the influence of work-life balance on employee performance in banking sectors only in Klang Valley, so further study should be done at another area. The methodology and tools of this study should be employed to establish the reliability of the study findings. This study also recommends to expand the study on work-life balance among other professions in Malaysia and ensure the comparative study between different profession and different area be done. Similar studies also should be conducted on the effectiveness of work-life balance policies and programs in organization and initiatives relates to employee satisfaction. Besides that, further studies also should be done related to HR Management in order to provide solutions to the work-life balance challenges in Human Resource Management.

The dual duty of women between job and family recently hinder work-life balance and limits their career progression (Narayanan and Savarimuthu, 2015). Since the demand of women to work are socially accepted nowadays, future research on women potentially would explore each of the variables separately that might have link on employee's performance. Due to some limitations such low responses and small sample size, the future research might consider expanding the sample size and also be carried out in other region with hectic lifestyle. In addition, comparative studies also can be done with other geographical area between urban or rural area among bank employees.

\section{References}

Adigun, A., and Bello, B. A. (2014). Influence of Employee Assistance Programmes On Commitment In Manufacturing Companies In Lagos State. International Journal of Information Technology and Business Management, 26(1).

Ali Ch., G. A., Kundi, G. M., Qureshi, Q. A., and Akhtar, R. (2014). Relationship between Work-Life Balance \& Organizational Commitment. Research on Humanities and Social Science, 4(5), 1-7.

Allen, T. D., Lapierre, L. M., Spector, P. E., Poelmans, S. A. Y., O’Driscoll, M., Sanchez, J. I., ... Woo, J. M. (2014). The Link Between National Paid Leave Policy and Work-Family Conflict Among Married Working Parents. Applied Psychology, 63(1), 5-28. http://doi.org/10.1111/apps.12004

Altindag, E., and Siller, F. (2014). Effects of Flexible Working Method on Employee Performance: An Empirical Study in Turkey. Business \& Economics Research Journal, 5(3), 1-7. http://doi.org/10.4172/2151$\underline{6219.1000104}$

Ashfaq, S., Mahmood, Z., and Ahmad, M. (2013). Impact of Work-Life Conflict and Work over Load on Employee Performance in Banking Sector of Pakistan. Middle-East Journal of Scientific Research, 14(5), 688-695. http://doi.org/10.5829/idosi.mejsr.2013.14.5.1754 
Aslam, M. (2015). Influence of Work Life Balance on Employees Performance : Moderated by Transactional Leadership. Journal of Resources Development and Management, 10, 98-103.

Bashir, U., \& Ramay, M. I. (2010). Impact of Stress on Employees Job Performance A Study on Banking Sector of Pakistan. Impact of Stress on Employees Job Performance A Study on Banking Sector of Pakistan, 2, 122-126. http://doi.org/0975-5853

Bashir, U., Sharma, R., Jauhari, S., Singh, V., Karunanithy, K., Ponnampalam, A., ... Naqvi, H. (2013). A Study on The Effect of Stress on Performance of Employees in Commercial Bank of Ceylon in The Eastern Province. Impact of Stress on Employees Job Performance A Study on Banking Sector of Pakistan, 5(2), 87-96. http://doi.org/0975-5853

Chiang, F. F. T., Birtch, T. A., and Kwan, H. K. (2010). The Moderating Roles of Job Control and Work-Life Balance Practices on Employee Stress in The Hotel And Catering Industry. International Journal of Hospitality Management, 29(1), 25-32. http://doi.org/10.1016/j.ijhm.2009.04.005

Darcy, C., Mccarthy, A., Hill, J., and Grady, G. (2012). Work - life balance : One Size Fits All ? An Exploratory Analysis Of The Differential Effects Of Career Stage, European Management Journal. 111-113. http://doi.org/10.1016/j.emj.2011.11.001

Dissanayaka, N. M. N. P., and Ali, M. A. M. H. (2011). Impact of Work - Life Balance on Employees Performance : An Empirical Study on Seven Apparel Organizations in Sri Lanka :, (1), 60-64.

Elnaga, A., and Imran, A. (2013). The Effect of Training on Employee Performance. European Journal of Business and Management, 5(4), 137-147. http://doi.org/10.2991/gecss-14.2014.90

Florida, C. (2015). A Social Network Analysis Approach to Strengthening Nonprofit Collaboration. Journal of Applied Management and Journal of Applied Management and Entrepreneurship, Vol. 20, No. 1

Gachunga, H., and Muchiti, E. (2015). Influence of Work Life Balance on Employee Productivity in Kenya; A Case of Milimani Law Courts Nairobi. Strategic Journal of Business \& Change Management, 2(48), $1-20$.

Kamau, J. M., Muleke, V., and Obino, S. (2013). Work-Life Balance Practices on Employee Job Performance at Eco Bank Kenya. European Journal of Business and Management, 5(25), 2222-2839.

Keino, D. C., and Kithae, D. P. P. (2016). Effects of Work Life Balance on Staff Performance in the Telecommunication Sector in Kenya. Archives of Business Research, 4(1), 129-138.

Khalil Omar, M., Husna Mohd, I., and Shafiq Ariffin, M. (2015). Workload, Role Conflict and Work-Life Balance Among Employees of an Enforcement Agency in Malaysia. International Journal of Business, Economics and Law, 8(2), 52-57.

Khatri, P. V., and Behl, J. (2013). Impact of Work-Life Balance on Performance of Employees in the Organisations. Global Journal of Business Management, 7(1), 39-47.

Kim, H. K. (2014). Work- Life Balance and Employees 'Performance: The Mediating Role of Affective Commitment. Global Business and Management Research: An International Journal, 6(1), 37-51.

Kipkemoi, A. C., Omolo, J. W., and Lucy, A. O. (2016). Effect of On-The-Job Training on Employee Performance in Kenya : Case of Mumias Sugar Company Limited. Developing Countries Studies, 3(1), 7-24.

Kipkemoi, A. C., Omolo, R. D. J. W., and Onditi, D. A. L. (2016). Influence of Employee Assistance Programs on Employee Performance in Mumias Sugar Company, Kenya. Developing Countries Studies, 6(2), 169-172.

Lekgothoana, P., and Schultz, C. (2014). Employee Assistance Programmes as An Important Service at A Coal Mine in South Africa. Global Business and Technology Association, 296-305.

McCarthy, A., Darcy, C., and Grady, G. (2010). Work-Life Balance Policy and Practice: Understanding Line Manager Attitudes and Behaviors. Human Resource Management Review, 20(2), 158-167. http://doi.org/10.1016/j.hrmr.2009.12.001

Mungania, A. K. (2016). Influence of Work Life Conflict on Organizational Performance in The Banking Industry in Kenya. International Journal of Advanced Multidisciplinary Research, 3(8), 14-22.

Mwebi, M. B., and Kadaga, M. N. (2015). Effects of Flextime Work Arrangement on Employee Performance in Nairobi CBD Commercial Banks. International Journal of Novel Research in Marketing Management and Economics, 2(3), 111-121.

Narayanan, S. L., and A.Savarimuthu. (2015). Work-Family Conflict, Family-Work Conflict as Predictors of Work-Life Balance among Women Employees Working in IT industries. Internation Conference on Technolofy and Business Management, 634-639. 
Noor, K. (2011). Work-Life balance and intention to leave among academics in Malaysian public higher education institutions. International Journal of Business and Social Science, 2(11), 240-248. Retrieved from http://ijbssnet.com/journals/Vol._2_No._11_[Special_Issue-June_2011]/34.pdf

O'Brien, T., and Hayden, H. (2016). Flexible Work Practices and The LIS Sector: Balancing The Needs of Work and Life?, Library Management, $\quad$ Vol. 29 Iss 3 pp. $199 \quad-\quad 228$ http://doi.org/http://dx.doi.org/10.1108/MRR-09-2015-0216

Obiageli, O. L., Uzochukwu, O. C., and Ngozi, C. D. (2015). Work Life Balance and Employee Performance in Selected Commercial Banks in Lagos State. European Journal of Research and Reflection in Management Sciences, 3(4), 63-77.

Paul, M., Dutta, A., and Saha, P. (2015). Workplace Spirituality and Work-Life Balance: A Study among Women Executives of IT Sector Companies. International Journal of Management \& Behavioural Sciences, 6(June), 267-269. http://doi.org/10.13140/RG.2.1.1904.8807

Philipp, R. V., Francis, F., and Ramos, H. M. (2015). Work Life Balance and Quality of Life among Employees in Malaysia. International Journal Happiness and Development, 2(1), 38-51. http://doi.org/10.1504/IJHD.2015.067598

Pradana, A., and Salehudin, I. (2015). Work Overload and Turnover Intention of Junior Auditors in Greater Jakarta, Indonesia. The South East Asian Journal of Management, 9(2), 108-124. http://doi.org/10.21002/seam.v9i2.4950

Shagvaliyeva, S., and Yazdanifard, R. (2014). Impact of flexible working hours on work-life balance. American Journal of Industrial and Business Management, 4(January), 20-23.

Tan, V., and Wong, W. (2015). Malaysian Banks Reducing Staff. Star Media Group Berhad. Retrieved from http://www.thestar.com.my/business/business-news/2015/09/17/banks-rightsizing-staff/

Tavassoli, T., \& Sune, A. (2015). Research Proposal on The Outcomes of Work-Life Balance in Spain And Iran, $1-14$.

Waehrer, G. M., Miller, T. R., Hendrie, D., and Galvin, D. M. (2016). Employee Assistance Programs, Drug Testing, and Workplace Injury. Journal of Safety Research, 57, 53-60. http://doi.org/10.1016/j.jsr.2016.03.009 